\title{
The significance of the degradation products of rapeseed meal proteins in the rumen according to different meal processing techniques
}

\author{
Jocelyne Aufrère*, Dominique Graviou, Camille Demarquilly \\ Inra, Unité Valeur Alimentaire, SRNH, Theix, 63122 Saint-Genès-Champanelle, France
}

(Received 22 September 1997; accepted 19 December 1997)

\begin{abstract}
The extent to which rumen soluble nitrogen can contribute to the intestinal protein flow is unknown. Therefore, a study was carried out to assess simultaneously the kinetics of: 1) protein disappearance from rumen bags; 2 ) the amount of various $\mathrm{N}$ products in the rumen fluid contents (total nitrogen $(\mathrm{Nt})$, ammonia $\mathrm{N}(\mathrm{NH} 3-\mathrm{N})$, non-ammonia nitrogen (NAN), true protein); and 3) electrophoretical characteristics of the protein in feeds, bag residues and ruminal fluids. Measurements were made on four sheep fed successively with five diets: hay alone (basal) or hay plus one of four rapeseed oilmeals ( $60 \%$ hay, $40 \%$ meals). Oilmeal batches originated from different heating and solvent extraction processes: control at $60^{\circ} \mathrm{C}\left(\mathrm{T} 60^{\circ}\right)$, commercial (TC), and experimental at $90^{\circ} \mathrm{C}\left(\mathrm{T} 90^{\circ}\right)$ or $130^{\circ} \mathrm{C}\left(\mathrm{T} 130^{\circ}\right)$. They differed in their effective protein degradability as assessed by an in situ method which gave results of $0.83,0.69,0.39,0.42$ respectively for $\mathrm{T} 60^{\circ}, \mathrm{TC}, \mathrm{T} 90^{\circ}$ and $\mathrm{T} 130^{\circ}$. In the rumen fluid, the Nt and NAN contents peaked $1 \mathrm{~h}$ after feeding and then decreased rapidly (for the $7 \mathrm{~h}$ post-feeding). The NAN peak level was generally higher for highly degradable oilmeals $\left(0.56 \mathrm{mg} / \mathrm{g}\right.$ and $0.36 \mathrm{mg} / \mathrm{g}$ respectively in diets containing $\mathrm{T} 60^{\circ}$ and TC) than for low-degradable oilmeals $(0.15 \mathrm{mg} / \mathrm{g}$ and $0.23 \mathrm{mg} / \mathrm{g})$ in diets containing $\mathrm{T} 90^{\circ}$ and $\mathrm{T} 130^{\circ}$. NH3 $-\mathrm{N}$ was fairly high $(0.3 \mathrm{mg} / \mathrm{g})$ whatever the oilmeal, due to the high $\mathrm{CP}$ content of the diet $(21 \%)$ and showed only small variations in the post-feeding hours. At peak time, the NAN/Nt ratios in rumen fluid were $0.61,0.52,0.30$ and $0.42 \mathrm{mg} / \mathrm{g}$ respectively in diets containing $\mathrm{T} 60^{\circ}$, $\mathrm{TC}, \mathrm{T} 90^{\circ}$ and $\mathrm{T} 130^{\circ}$. The true protein- $\mathrm{N}$ was roughly the same and low whatever the time, for the diets containing $\mathrm{T} 90^{\circ}$ and $\mathrm{T} 130^{\circ}$, but true-protein- $\mathrm{N}$ was $0.30 \mathrm{mg} / \mathrm{g} 1 \mathrm{~h}$ after feeding for $\mathrm{T} 60^{\circ}$ and TC. Using electrophoresis (SDS-PAGE), feed proteins had similar characteristics among oilmeals, though extraction yields differed widely: $70 \%, 52 \%, 21 \%$ and $19 \%$ respectively for $\mathrm{T} 60^{\circ}, \mathrm{TC}, \mathrm{T} 90^{\circ}$ and $\mathrm{T} 130^{\circ}$. The main proteins contained in the oilmeals are $2 \mathrm{~S}$ and $12 \mathrm{~S}$, which were degraded in nylon bags in the rumen at various degradation rates. Similar proteins were found in the bag residues for various times apparently related to degradability: up to $8 \mathrm{~h}, 16 \mathrm{~h}, 24 \mathrm{~h}$ and $24 \mathrm{~h}$ respectively for $\mathrm{T} 60^{\circ}, \mathrm{TC}, \mathrm{T} 90^{\circ}$ and $\mathrm{T} 130^{\circ}$. They were also observed in rumen fluid for $\mathrm{l} \mathrm{h}$ and $2 \mathrm{~h}$ post-feeding for $\mathrm{T} 60^{\circ}$ and TC respectively. Therefore, it appeared that there could be some rumen outflow of solubilized protein. Here, whatever the oilmeal, this outflow would represent
\end{abstract}

* Correspondence and reprints.

Tel.: (33) 0473624072 ; fax: (33) 0473624273 ; e-mail: aufrere@ clermont.inra.fr 
5 to $7 \%$ of the amount of degraded protein (assuming the passage rate of rumen fluid in sheep to be $0.07 \mathrm{~h}^{-1}$ ). New protein systems could therefore underestimate the potential protein by-pass unless their calibration is based on the duodenal protein flow (such as the Inra system). (@ Elsevier / Inra)

\title{
rapeseed meal / technological processes / nitrogen degradation / rumen fluid composition / electrophoresis
}

\begin{abstract}
Résumé - Importance des produits de dégradation dans le rumen des protéines du tourteau de colza suivant les traitements technologiques subis. L'importance du flux d'azote solubilisé dans le rumen pouvant contribuer au flux d'azote intestinal est mal connu. C'est pourquoi une étude a été conduite pour estimer simultanément en cinétique : 1) la disparition des protéines des sachets de nylon déposés dans le rumen ; 2) la teneur en différentes fractions azotées du jus de rumen (azote total $\left(\mathrm{N}_{\mathrm{t}}\right)$, azote ammoniacal $\left(\mathrm{NNH}_{3}\right)$, azote non ammoniacal (NAN), $\mathrm{N}$ protéique); 3) la caractérisation des protéines des aliments, des résidus de sachets et du jus de rumen par électrophorèse. Les mesures ont été effectuées sur quatre moutons nourris successivement avec cinq régimes : foin seul (régime de base), foin plus un des quatre tourteaux dans la proportion $60 \%$ de foin, $40 \%$ de tourteau. Les tourteaux étudiés, issus d'un même lot de graines, avaient subi des traitements technologiques différents lors de la cuisson et de de la désolvantation : un tourteau témoin $\left(\mathrm{T} 60^{\circ}\right)$, un tourteau commercial (TC), et deux tourteaux expérimentaux, chauffés à $90^{\circ} \mathrm{C}$ $\left(\mathrm{T} 90^{\circ}\right)$ et $130^{\circ} \mathrm{C}\left(\mathrm{T} 130^{\circ}\right)$. Leur dégradabilité théorique estimée à partir de la méthode des sachets de nylon était respectivement de : 0,$83 ; 0,69 ; 0,39 ; 0,42$, pour $\mathrm{T} 60^{\circ}, \mathrm{TC}, \mathrm{T} 90^{\circ}, \mathrm{T} 130^{\circ}$. Dans le jus de rumen, les teneurs en Nt et NAN sont élevées $1 \mathrm{~h}$ après le repas et diminuent rapidement (jusqu'à $7 \mathrm{~h}$ après le repas). Le pic de NAN est plus élevé pour les tourteaux les plus dégradables $\left(0,56 \mathrm{mg} / \mathrm{g}\right.$ et $0,36 \mathrm{mg} / \mathrm{g}$ respectivement pour les rations contenant $\mathrm{T} 60^{\circ}$ et $\left.\mathrm{TC}\right)$ que pour les moins dégradables $\left(0,15 \mathrm{mg} / \mathrm{g}\right.$ et $0,23 \mathrm{mg} / \mathrm{g}$ dans les rations contenant $\mathrm{T} 90^{\circ}$ et $\left.\mathrm{T} 130^{\circ}\right)$. En raison de la teneur élevée en azote de la ration, la concentration en $\mathrm{NNH}_{3}$ reste élevée $(0,3 \mathrm{mg} / \mathrm{g})$ pour tous les tourteaux quel que soit le temps de la cinétique. $1 \mathrm{~h}$ après le repas, la teneur en NAN dans le jus de rumen est maximale soit de 0,$61 ; 0,52 ; 0,30$ et $0,42 \mathrm{mg} / \mathrm{g}$ respectivement pour les rations contenant $\mathrm{T} 60^{\circ}, \mathrm{TC}, \mathrm{T} 90^{\circ}$ et $\mathrm{T} 130^{\circ}$. La teneur en $\mathrm{N}$ protéique est faible pour $\mathrm{T} 90^{\circ}$ et $\mathrm{T} 130^{\circ}$ mais on observe un pic $(0,30 \mathrm{mg} / \mathrm{g}) 1 \mathrm{~h}$ et $2 \mathrm{~h}$ après le repas pour $\mathrm{T} 60^{\circ}$ et TC respectivement. Les résultats des électrophorèses indiquent que les protéines ont les mêmes caractéristiques pour les différents tourteaux bien que les pourcentages d'extraction soient très différents $\left(70 \%, 52 \%, 21 \%, 19 \%\right.$, respectivement pour $\mathrm{T} 60^{\circ}, \mathrm{TC}, \mathrm{T} 90^{\circ}$ et $\left.\mathrm{T} 130^{\circ}\right)$. Les protéines majeures sont des protéines $2 \mathrm{~S}$ (de poids moléculaire 8000 à 10000 ) et $12 \mathrm{~S}$ (de poids moléculaire 18000 à 30000 ). Ces mêmes protéines sont trouvées dans les résidus de sachets jusqu'à des temps plus ou moins longs selon leur dégradation mesurée par la méthode des sachets (jusqu'à $8 \mathrm{~h}, 16 \mathrm{~h}, 24 \mathrm{~h}$ et $24 \mathrm{~h}$ respectivement pour $\mathrm{T} 60^{\circ}, \mathrm{TC}, \mathrm{T} 90^{\circ}$ et $\mathrm{T} 130^{\circ}$ ). On trouve également des protéines dans le jus de rumen $1 \mathrm{~h}$ et $2 \mathrm{~h}$ après le repas pour $\mathrm{T} 60^{\circ}$ et TC. Ces résultats confiment que des protéines solublisées des sachets ruminaux peuvent échapper à la dégradation dans le rumen. Quel que soit le tourteau étudié, la proportion de NAN par rapport aux protéines dégradées (calculées à partir de la dégradation en sachets de nylon) est de 5 à $7 \%$. (pour un taux de sortie de la phase liquide chez le mouton de $0,07 \mathrm{~h}^{-1}$ ). Les nouveaux systèmes d'évaluation de la valeur azotée peuvent sous-estimer les protéines by-pass à moins qu'ils ne soient calibrés sur des flux duodénaux comme dans le système Inra. (@) Elsevier/Inra)
\end{abstract}

tourteau de colza / traitement technologique / dégradation de l'azote / composition du jus de rumen / électrophorèse

\section{INTRODUCTION}

The true protein value of a diet for ruminants depends largely on the extent to which feed proteins escape rumen degradation. In most modern protein systems, rumen by-pass of proteins is assessed from the nylon bag method [48]. 
However, several shortcomings of this method have been identified [19, 34]. For example, the assumption that $\mathrm{N}$ disappearing from bags would be completely degraded to ammonia $\mathrm{N}$ and could not, therefore, contribute to the protein by-pass is questionable.

The purpose of this study was to check whether solubilized feed $\mathrm{N}$ products could outflow from rumen before being degraded to ammonia. Four rapeseed meals produced from the same seed batch and submitted to different technological treatments were studied.

\section{MATERIALS AND METHODS}

\subsection{Feeds}

The study was carried out on four different rapeseed meals prepared from the same Eurol type seed batch, under the trituration conditions described below:

- eight n-hexane washes of the flaked seeds at a temperature below $60^{\circ} \mathrm{C}$, followed by solvent extraction at $80^{\circ} \mathrm{C}$ with steam injection (direct extraction process minimizing the heating of the seeds $\left(\mathrm{T} 60^{\circ}\right)$ );

- heat treatment at $90^{\circ} \mathrm{C}$, followed by solvent extraction at $105^{\circ} \mathrm{C}$, with steam injection at $50 \mathrm{~kg} / \mathrm{h}$ (conventional industrial process TC);

- heat treatment at $90^{\circ} \mathrm{C}$, followed by solvent extraction at $108{ }^{\circ} \mathrm{C}$, with steam injection at $120 \mathrm{~kg} / \mathrm{h}\left(\mathrm{T} 90^{\circ}\right)$;

- heat treatment at $130^{\circ} \mathrm{C}$, followed by solvent extraction at $120^{\circ} \mathrm{C}$, with steam injection at $80 \mathrm{~kg} / \mathrm{h}\left(\mathrm{T} 130^{\circ}\right)$.

These triturations were carried out in the Cetiom pilot plant (Pessac, France).

\subsection{Animals and experimental design}

Four ruminally cannulated Texel sheep were used in the experiment. The rapeseed meal given to the sheep was the same as the one whose degradability had been studied in nylon bags. The dry matter intake was limited to $40 \mathrm{~g}$ per $\mathrm{kg}$ of metabolic weight per day.
The experiment had five experimental periods of animal feeding using successively one of the four rapeseed meals (with hay) or with hay alone (last period). Each period had a 2-week adaptation phase and 2 weeks for measurements. The first period was for measuring the in situ degradation kinetics of the rapeseed meal, and the second period for the kinetic sampling of ruminal fluids, which were carried out for all animals.

\section{In situ degradation}

Nitrogen degradability was measured using the nylon bag procedure, as described by Michalet-Doreau et al. [32]. About $3 \mathrm{~g}$ of the samples ( $8 \mathrm{~mm}$ mesh) were weighed into bags. The sample was then incubated in the rumen of the four fistulated sheep fed a $40 \%$ rapeseed meal diet. The rapeseed meal in the diet was the same as used in the nylon bag. Incubation periods were $2,4,8,16,24,48 \mathrm{~h}$ for $\mathrm{T} 60^{\circ}$ and $\mathrm{TC}$ and $2,4,8,16,24,48,72 \mathrm{~h}$ for $\mathrm{T} 90^{\circ}$ and $\mathrm{T} 130^{\circ}$. After the bags were removed from the rumen, they were kept at $-15^{\circ} \mathrm{C}$ until being analyzed. Prior to analysis, the bags were defrosted, then rinsed with cold water until the water ran clear. The bags were then beaten for $7 \mathrm{~min}$ in a 'stomacher' [29], washed again and finally dried at $60^{\circ} \mathrm{C}$ for $48 \mathrm{~h}$. The solubility of the nitrogen without incubation in the rumen $(0 \mathrm{~h})$ was determined by soaking bags containing the samples in warm water $\left(40^{\circ} \mathrm{C}\right)$ for $2 \mathrm{~h}$, then drying them as before.

\subsection{Ruminal fluid sampling}

Samples of ruminal fluid were taken from the sheep on 2 consecutive days, before the morning feed ( $0 \mathrm{~h}$ time) and $\mathrm{l}, 2,4$ and $7 \mathrm{~h}$ after the meal. $150 \mathrm{~mL}$ of ruminal fluid were taken and muslin-filtered, then centrifuged for $5 \mathrm{~min}$ at $120 \mathrm{~g}$ in order to remove nutritional particles and protozoa. The supernatant was centrifuged at $4{ }^{\circ} \mathrm{C}, 27000 \mathrm{~g}$ for $20 \mathrm{~min}$ to remove nutritional particles and bacteria. The protein was then precipitated with sulfosalycilic acid (400 g/L) and separated after centrifugation $(20000 \mathrm{~g}$ for $10 \mathrm{~min})$. 


\subsection{Analyses}

The granulometry of the rapeseed meal was carried out according to Grenet [17]. The total nitrogen (Nt) content of the feeds, bag residues, as well as the soluble nitrogen of the ruminal fluids (before and after precipitation with sulfosalycilic acid) were determined using the Kjeldahl method. The protein contents of the ruminal fluid $\mathrm{N}$ content values were obtained from the difference, and the NH3-N values were determined from the acid supernatant (after precipitation with sulfosalycilic acid) according to the Conway method [10].

Enzymatic degradability for the rapeseed meals was measured at time $1 \mathrm{~h}$ (DE1) [1]

The cell-wall contents (NDF and ADF) were determined for the feeds using the Van Soest [44] and Van Soest and Wine [45] methods, modified by Giger et al. [15] and Dorléans et al. [13], by carrying out a preliminary treatment with an amylase and a protease. The neutral-detergent-insoluble nitrogen (NDIN) and acid-detergent-insoluble nitrogen (ADIN) were also determined.

\subsection{Protein separation procedures}

The procedure of Bhatty et al. [6] was used. Feed proteins were extracted with $10 \% \mathrm{NaCl}$ $(w / v)$. The extract was centrifuged at $20^{\circ} \mathrm{C}$, $36000 \mathrm{~g}$ for $20 \mathrm{~min}$. The supernatant was dialyzed for $92 \mathrm{~h}$ with distilled water. The globulins were precipitated and separated from the albumins. After centrifuging, the albumins were precipitated in TCA $20 \%(\mathrm{w} / \mathrm{v})$, then the proteins were solubilized in the extraction solution.

Purified proteins and proteins from the ruminal fluid were precipitated with sulfosalycilic acid $(40 \mathrm{~g} / 100 \mathrm{~mL})$, centrifuged $(10 \mathrm{~min}$ at $20000 \mathrm{~g})$ and washed with ether ethanol $(v / v)$ before extraction.

\subsection{Electrophoresis}

The rapeseed meals and their residues after in situ degradation were fractionated using sodium dodecyl sulfate-polyacrylamide gel electrophoresis (SDS-PAGE) according to the modified procedure of Laemmli [21]. The proteins in the residues were extracted in an extrac- tion solution ( $1 \mathrm{M}$ Tris- $\mathrm{HCl}$, pH 6.8, glycerol, SDS, pyronin, $\beta$-mercaptoethanol and distilled water) in the proportion of $750 \mu \mathrm{L}$ per $1 \mathrm{mg}$ nitrogen (based on the Kjeldahl method). The gels $(80-100 \mathrm{~mm})$ consisted of a stacking gel containing $125 \mathrm{mM}$ Tris- $\mathrm{HCl}(\mathrm{pH} 6.8$ ) plus $3.75 \%$ acrylamide $(30 \% \mathrm{C}=5 \%)$ and $1 \% \mathrm{SDS}$ $(0.1 \mathrm{~g} / \mathrm{mL})$, polymerized with $0.5 \%$ ammonium persulphate $(15 \%), 0.094 \%$ tetramethylethylendiamine approximately $30 \mathrm{~mm}$ high, layered over a separating gel. The separating gel contained $15 \%$ acrylamide-bisacrylamide $(30 \% \mathrm{C}=5 \%), 37.5 \% 1 \mathrm{M}$ Tris- $\mathrm{HCl}(\mathrm{pH} 8.8)$ and $1 \%$ SDS $(0.1 \mathrm{mg} / \mathrm{mL})$, polymerized with $0.5 \%$ ammonium persulphate $(0.15 \mathrm{~g} / \mathrm{mL})$ and $0.083 \%$ tetramethyl-ethylendiamine. Electrophoresis was carried out for approximately $1.5 \mathrm{~h}$ at $200 \mathrm{~V}$. The gels were then stained with a $0.2 \%$ solution of Coomassie brilliant blue $R$ in $10 \%$ acetic acid (w/v) and $25 \%$ 2-propanol $(\mathrm{w} / \mathrm{v})$ for $30 \mathrm{~min}$ at $20^{\circ} \mathrm{C}$ to detect the protein band. This was followed by de-staining with a solution of $10 \%$ acetic acid $(\mathrm{v} / \mathrm{v})$ and $35 \%$ ethanol $(\mathrm{w} / \mathrm{v})$ for $45 \mathrm{~min}$

The protein subunit molecular masses were determined with a standard protein solution consisting of lactalbumin $\left(M_{\mathrm{r}} 14200\right)$, trypsin inhibitor $\left(M_{\mathrm{r}} 20100\right)$, trypsinogen $\left(M_{\mathrm{r}} 24200\right)$, carbonic anhydrase $\left(M_{\mathrm{r}} 29000\right)$; glyceraldehyde-3-phosphate deshydrogenase $\left(M_{\mathrm{r}} 36000\right)$, ovalbumin $\left(M_{\mathrm{r}} 45000\right)$ and bovine plasma albumin $\left(M_{\mathrm{r}} 66000\right)$.

\subsection{Calculations and statistical analysis}

The in situ DM and $\mathrm{N}$ disappearances in hay and rapeseed meals were fitted to the model of Orskov and McDonald [33] using a non-linear regression procedure [35]: $\% N$ degraded $=a+b\left(1-e^{-c t}\right)$.

The effective degradability of nitrogen $\operatorname{Deg}(\mathrm{N})$ was calculated as Deg $(\mathrm{N})=\mathrm{a}+(\mathrm{bc}) /(\mathrm{c}$ $+\mathrm{kp}$ ) assuming $\mathrm{kp}=0.06 \mathrm{~h}^{-}[20]$.

The same model was used to calculate the effective degradability of dry matter $(\operatorname{Deg}(\mathrm{DM}))$.

The various degradability parameters for the nylon bags were analyzed by a variance analysis [35] according to the following factorial model:

$$
Y=M+A i+T j+E i j
$$


where $\mathrm{M}$ is the overall average, Ai the animal effect, T $j$ the rapeseed meal effect; and Eij the residual error.

Since no significant difference appeared between the two measurement days for the parameters measured in the ruminal fluid, the average values of the two measurement days were analyzed following the same factorial model.

\section{RESULTS}

\subsection{Chemical analyses}

The chemical composition of the feeds is shown in table I. The contents in NDF, ADF,
NDIN, ADIN were similar for $\mathrm{T} 60^{\circ}$ and TC but much higher for $\mathrm{T} 90^{\circ}$ and $\mathrm{T} 130^{\circ}$.

The average diameters of the rapeseed meal particles were $0.25 \mathrm{~mm}, 0.35 \mathrm{~mm}, 0.36 \mathrm{~mm}$ and $0.24 \mathrm{~mm}$ respectively for $\mathrm{T} 60^{\circ}, \mathrm{TC}, \mathrm{T} 90^{\circ}$ and $\mathrm{T} 130^{\circ}$.

\subsection{In situ study (table II)}

All degradation parameter values for $\mathrm{N}$ and DM were similar for $\mathrm{T}^{\circ} 0^{\circ}$ and $\mathrm{T} 130^{\circ}$ and significantly different from $\mathrm{T} 60^{\circ}$; the values for $\mathrm{TC}$ were intermediate. For both $\mathrm{T} 90^{\circ}$ and $130^{\circ}$, the degradability rate was very low. Deg values for $\mathrm{N}$ and $\mathrm{DM}$ were higher for $\mathrm{T} 60^{\circ}$ than for $\mathrm{TC}$ and both were higher than $\mathrm{T} 90^{\circ}$ and $\mathrm{T} 130^{\circ}$ respectively.

Table I. Chemical composition of the rapeseed meals and hay.

\begin{tabular}{lccccc}
\hline & T60 & TC & T90 & T130 & Control hay \\
\hline Nt (\% DM) & 5.77 & 5.93 & 5.93 & 6.10 & 1.25 \\
DE1 (\% Nt) & 66.26 & 38.14 & 15.37 & 12.24 & \\
NDF(\% DM) & 29.19 & 30.06 & 41.54 & 48.66 & 65.00 \\
ADF (\% DM) & 21.77 & 20.62 & 25.68 & 29.69 & 40.12 \\
NDIN (\% Nt) & 11.23 & 14.37 & 37.60 & 52.25 & 40.04 \\
ADIN (\% Nt) & 8.45 & 7.62 & 20.10 & 25.39 & 9.30 \\
\hline
\end{tabular}

DM, dry matter: Nt, total nitrogen.

Table II. In situ degradation parameters for rapeseed meals.

\begin{tabular}{lcccc}
\hline & $\mathrm{T} 60^{\circ}$ & $\mathrm{TC}$ & $\mathrm{T} 90^{\circ}$ & $\mathrm{T} 130^{\circ}$ \\
\hline $\mathrm{DM}$ & & & & \\
$\mathrm{a}$ & $0.310^{\mathrm{a}}$ & $0.265^{\mathrm{b}}$ & $0.217^{\mathrm{c}}$ & $0.211^{\mathrm{c}}$ \\
$\mathrm{b}$ & $0.482^{\mathrm{a}}$ & $0.606^{\mathrm{b}}$ & $0.680^{\mathrm{c}}$ & $0.684^{\mathrm{c}}$ \\
$\mathrm{c}$ & $0.354^{\mathrm{a}}$ & $0.103^{\mathrm{b}}$ & $0.041^{\mathrm{b}}$ & $0.036^{\mathrm{b}}$ \\
$\operatorname{Deg}(\mathrm{DM})$ & $0.717^{\mathrm{a}}$ & $0.644^{\mathrm{b}}$ & $0.486^{\mathrm{c}}$ & $0.468^{\mathrm{c}}$ \\
$\mathrm{N}$ & & & & \\
$\mathrm{a}$ & & & & \\
$\mathrm{b}$ & $0.348^{\mathrm{a}}$ & $0.248^{\mathrm{b}}$ & $0.102^{\mathrm{c}}$ & $0.094^{\mathrm{c}}$ \\
$\mathrm{c}$ & $0.553^{\mathrm{a}}$ & $0.694^{\mathrm{b}}$ & $0.898^{\mathrm{c}}$ & $0.906^{\mathrm{c}}$ \\
$\operatorname{Deg}(\mathrm{N})$ & $0.424^{\mathrm{a}}$ & $0.108^{\mathrm{b}}$ & $0.029^{\mathrm{b}}$ & $0.034^{\mathrm{b}}$ \\
\hline
\end{tabular}

DM, dry matter; $\mathrm{N}$, nitrogen. a, rapidly degraded fraction (\%); b, slowly degraded fraction (\%); $\mathrm{c}$, rate of degradation $\left(\mathrm{h}^{-1}\right)$; Deg, degradability $(\%) \mathrm{a}+\mathrm{bc} / \mathrm{c}+\mathrm{k}$; different subscripts in a same line correspond to a significant difference $(P<0.05)$. 
For $\mathrm{T} 90^{\circ}$ and $\mathrm{T} 130^{\circ}$ the fitting model was imperfect because the sum of the soluble fraction and the potentially degraded nitrogen fraction was close to 100 even though the percentage of residual nitrogen at $72 \mathrm{~h}$ was about $7 \% \mathrm{Nt}$. Inversely, for $\mathrm{T} 60^{\circ}$ and $\mathrm{TC}$, the asymptote was reached respectively at $16 \mathrm{~h}$ and $24 \mathrm{~h}$.

However, Deg ( $\mathrm{N}$ ) was significantly higher for $\mathrm{T} 60^{\circ}$ and $\mathrm{TC}$ because the (a) fractions were higher, whereas the (b) fractions were lower and had a higher degradation rate (c), particularly for $\mathrm{T} 60^{\circ}$.

\subsection{Ruminal fluid composition: Ntotal (Nt), non ammonia $\mathbf{N}$ (NAN), ammonia $\mathbf{N}(\mathbf{N H 3} \mathbf{N})$, protein nitrogen (protein- $\mathrm{N}$ )}

NAN is the difference between Nt and NH3-N. It therefore consists of amino acids, peptides and protein- $\mathrm{N}$ (true protein). For all diets and the various nitrogen fractions, (Nt, NH3-N, NAN protein-N) (figures l, 2, 3, 4) the concentrations observed in the ruminal fluid were higher at time $0 \mathrm{~h}$ than at time $7 \mathrm{~h}$. The $\mathrm{Nt}$, and NAN contents in the ruminal fluid were highest $1 \mathrm{~h}$ after feeding and diminished gradually until $7 \mathrm{~h}$ after feeding. For all sampling times, the various nitrogen fractions were the lowest $(P<0.05)$ for the hay ration and the highest for the ration containing $\mathrm{T} 60^{\circ}$. For diets containing $\mathrm{T} 90^{\circ}$ and $\mathrm{T} 130^{\circ}$, the Nt, NH3-N, NAN contents of the ruminal fluid did not show any significant differences between them $(P>0.05)$ for each sampling time. They were lower than those for the ration containing $\mathrm{T} 60^{\circ}$ and TC. One hour after feeding, the ruminal fluid for the $\mathrm{T} 60^{\circ}$ ration had a $\mathrm{Nt}$ content $(0.926 \mathrm{mg} / \mathrm{g})$ nearly twice as high as for diets containing $\mathrm{T} 90^{\circ}(0.508 \mathrm{mg} / \mathrm{g})$ and $\mathrm{T} 130^{\circ}$ $(0.546 \mathrm{mg} / \mathrm{g})$. This ratio decreased to 1.3 times at time $7 \mathrm{~h}$. At peak time, NAN/Nt ratios in rumen fluid were $0.61,0.52,0.30$ and 0.42 respectively for $\mathrm{T} 60^{\circ}, \mathrm{TC}, \mathrm{T} 90^{\circ}$ and $\mathrm{T} 130^{\circ}$.

The ruminal fluid NH3-N contents reached a maximum $4 \mathrm{~h}$ after feeding for the ration containing $\mathrm{T} 60^{\circ}, 2 \mathrm{~h}$ after feeding for those containing $\mathrm{T} 130^{\circ}$ and $\mathrm{TC}$ and $\mathrm{l} \mathrm{h}$ after feeding for the ration containing $\mathrm{T} 90^{\circ}$. It reached its minimum $7 \mathrm{~h}$ after feeding for all diets. This pattern was not the same as that of Nt. For Nt, the concentrations varied much less between sampling times and the kinetic profiles were different. In contrast with results obtained for Nt con- tent, the ruminal fluid from the ration containing $\mathrm{T} 60^{\circ}$ had only a significantly higher NH3$\mathrm{N}$ content than $\mathrm{T} 90^{\circ}$ and $\mathrm{T} 130^{\circ}$ at times $2 \mathrm{~h}, 4 \mathrm{~h}$ and $7 \mathrm{~h}$, and was not significantly different from the TC ration at times $2 \mathrm{~h}$ and $7 \mathrm{~h}$.

The NH3-N/Nt ratio in the ruminal fluid was only $39 \%$ at time $1 \mathrm{~h}$, and $50.5 \%$ at time $2 \mathrm{~h}$ for the ration containing $\mathrm{T} 60^{\circ}, 47 \%$ at time $1 \mathrm{~h}$ and $60.4 \%$ at time $2 \mathrm{~h}$ for the ration containing TC, while at time $7 \mathrm{~h}$ it was $75 \%$ for both diets. On the other hand, the NH3-N contents in the ruminal fluid for diets containing $\mathrm{T} 90^{\circ}$ and $\mathrm{T} 130^{\circ}$ were $60 \%$ to $70 \% \mathrm{Nt}$, and showed little variation throughout the sampling period.

On average, the true protein contents (figure 4) were low and only the ruminal fluid from the diets containing $\mathrm{T} 60^{\circ}$ and $\mathrm{TC}$ had high amounts of protein- $\mathrm{N}$ at $\mathrm{I} \mathrm{h}$ and $2 \mathrm{~h}$ after feeding (respectively $34.8 \% \mathrm{Nt}$ and $24.7 \% \mathrm{Nt}$ at $1 \mathrm{~h}$ after feeding, and $31.5 \% \mathrm{Nt}, 19.2 \% \mathrm{Nt}$ at $2 \mathrm{~h}$ after feeding). These amounts were significantly different from the ones found in the ruminal fluid from diets containing rapeseed meals $\mathrm{T} 90^{\circ}$ and $\mathrm{T} 130^{\circ}(P<0.05)$ for which the true protein contents were very low (about $7 \% \mathrm{Nt}$ ). For diets containing $\mathrm{T} 60^{\circ}$ and $\mathrm{TC}$, the true protein contents found in ruminal fluid decreased to $7 \% \mathrm{Nt}$ at time $7 \mathrm{~h}$.

\subsection{Electrophoresis}

For rapeseed meals, the yield of protein $\mathrm{N}$ (as percentage of initial $\mathrm{N}$ ) obtained by the extraction procedure was $70 \%, 52 \%, 21 \%$ and $19 \%$ respectively for $\mathrm{T} 60^{\circ}, \mathrm{TC}, \mathrm{T} 90^{\circ}$ and $\mathrm{T} 130^{\circ}$. Rapeseed meal proteins consisted of a water soluble albumin fraction with 8000 to 10000 molecular mass and a globulin fraction soluble in saline solutions made up of polypeptides with 18000 to 20000 and 28000 to 30000 molecular mass. These same proteins were found in all meals, whether or not they had been treated.

In the bags, residual proteins were observed up to $8 \mathrm{~h}$ (figure 5) for $\mathrm{T} 60^{\circ}, 16 \mathrm{~h}$ for TC (results not shown) and $24 \mathrm{~h}$ for $\mathrm{T} 90^{\circ}$ and $\mathrm{T} 130^{\circ}$ (results not shown). Protein fractions (12S and 2S) disappeared at the same time for $\mathrm{T} 60^{\circ}$ and TC, while the 8000 molecular mass fractions disappeared first for $\mathrm{T} 90^{\circ}$ and $\mathrm{T} 130^{\circ}$. At time 0 (before feeding) proteins in the ruminal fluid could not be found by electrophoresis whereas, for the $\mathrm{T} 60^{\circ}$ and $\mathrm{TC}$, proteins with a 


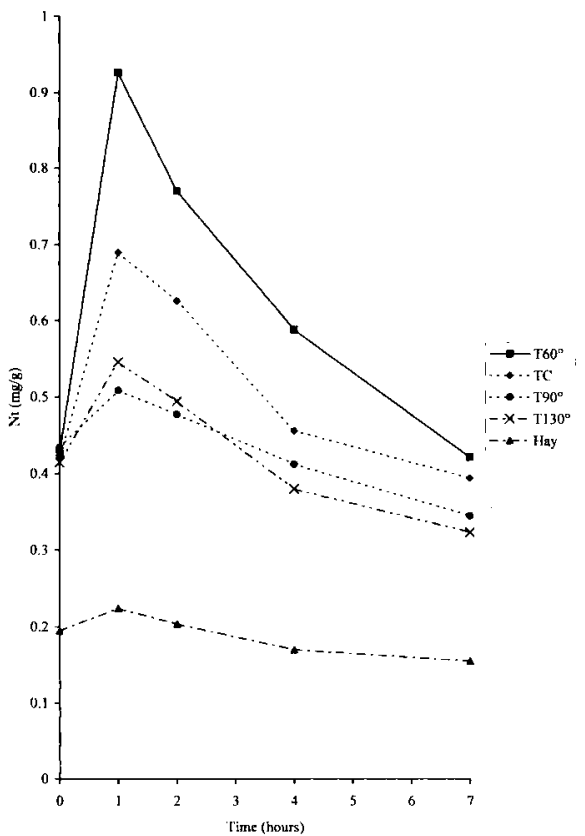

Figure 1. Evolution of the Nt content in rumen fluid for rations containing $\mathrm{T} 60^{\circ}, \mathrm{TC}, \mathrm{T} 90^{\circ}$, $\mathrm{T} 130^{\circ}$ and hay alone, before the morning feed (TOh) and $1 \mathrm{~h}, 2 \mathrm{~h}, 4 \mathrm{~h}$ and $7 \mathrm{~h}$ after feeding.

10000 to 30000 molecular mass were observed $1 \mathrm{~h}$ and $2 \mathrm{~h}$ after feeding (figure 5).

\section{DISCUSSION}

\subsection{Chemical composition and degradability}

The amounts of cell-wall contents for $\mathrm{T} 60^{\circ}$ and $\mathrm{TC}$ were normal for rapeseed meal $[4,20,36,43]$. The increased NDF and $\mathrm{ADF}$ contents in $\mathrm{T} 90^{\circ}$ and $\mathrm{T} 130^{\circ}$ were fully explained by the increase in their NDIN and ADIN fractions. The non $\mathrm{N}$ cell wall contents were similar for all rapeseed meals: $24-27 \%$ for (NDF-NDIN $\times$ 6.25 ) and $18-19 \%$ for (ADF-ADIN $x$ $6.25)$.

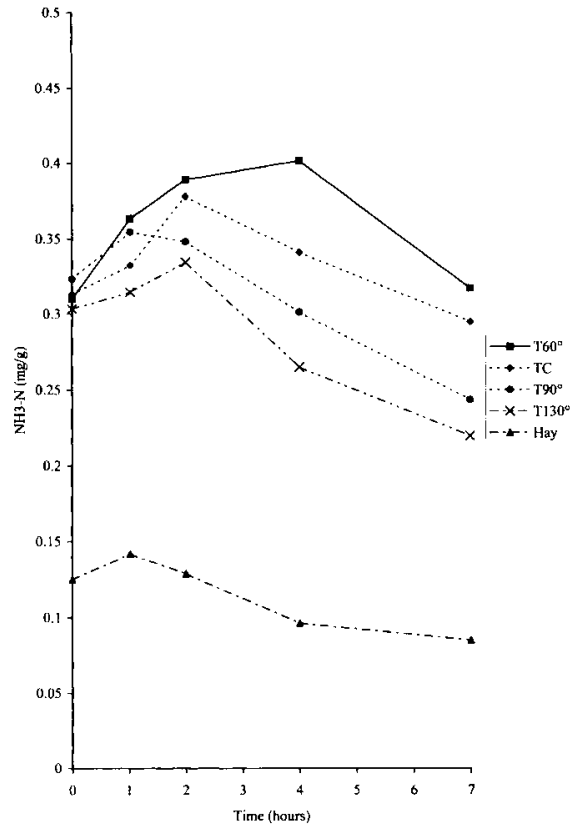

Figure 2. Evolution of the NH3-N content in rumen fluid for rations containing $\mathrm{T} 60^{\circ}, \mathrm{TC}$, $\mathrm{T} 90^{\circ}, \mathrm{T} 130^{\circ}$ and hay alone, before the morning feed (TOh) and $1 \mathrm{~h}, 2 \mathrm{~h}, 4 \mathrm{~h}$ and $7 \mathrm{~h}$ after feeding.

There were no significant $\operatorname{Deg}(\mathrm{N})$ variations between $\mathrm{T} 90^{\circ}$ and $\mathrm{T} 130^{\circ}$, although we might have expected a lower degradability for $\mathrm{T} 130^{\circ}$. Indeed, for $\mathrm{T} 130^{\circ}$, the cell-wall $\mathrm{N}$ content was higher, the DEl value was lower and the sum of the cooking and solvent extraction temperatures was higher than for $\mathrm{T} 90^{\circ}$. The lower mean particle size for $\mathrm{T} 130^{\circ}(0.24 \mathrm{~mm})$ compared to $\mathrm{T} 90^{\circ}(0.36 \mathrm{~mm})$ could explain the higher degradability for $\mathrm{T} 130^{\circ}$ due to greater particle losses in the bags. Furthermore, the finer particles might facilitate microbial enzymatic degradation in the rumen.

The low-heat treated rapeseed meal $\left(\mathrm{T} 60^{\circ}\right)$ had a very high $\operatorname{Deg}(\mathrm{N})$ as well as a very high (a) fraction and (c) degradation 


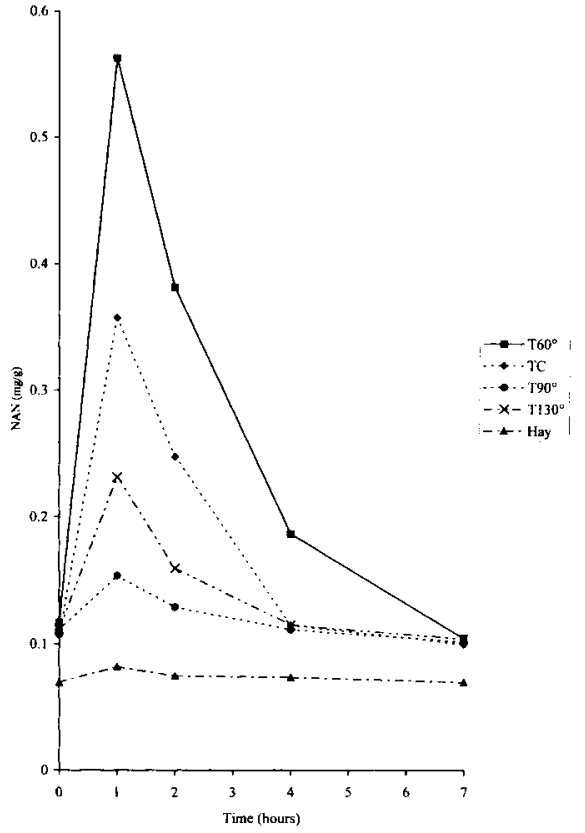

Figure 3. Evolution of the non-ammonia nitrogen (NAN) content in rumen fluid (peptides- $N$ + protein- $\mathrm{N}+$ amino acids- $\mathrm{N}$ ) for rations containing $\mathrm{T} 60^{\circ}, \mathrm{TC}, \mathrm{T} 90^{\circ}, \mathrm{T} 130^{\circ}$ and hay alone, before the morning feed (TOh) and $1 \mathrm{~h}, 2 \mathrm{~h}, 4 \mathrm{~h}$ and $7 \mathrm{~h}$ after feeding.

rate. The $\operatorname{Deg}(\mathrm{N})$ value obtained for $\mathrm{TC}$ (0.69) was similar to other published results $[11,18,20,24,47]$. The $\operatorname{Deg}(\mathrm{N})$ for $\mathrm{TC}$, which was higher for $\mathrm{T} 90^{\circ}$ and $\mathrm{T} 130^{\circ}$, was consistent with the sum of temperatures undergone in the heating of the seeds and solvent extraction, and therefore lower than for $\mathrm{T} 90^{\circ}$ and $\mathrm{T} 130^{\circ}$.

Heat treatment reduced the $\operatorname{Deg}(\mathrm{N})$ for $\mathrm{T} 90^{\circ}(0.39)$ and $\mathrm{T} 130^{\circ}(0.42)$. The $\operatorname{Deg}(\mathrm{N})$ decreased by around 0.30 , and this is higher than results of Bertilson et al. [5] ( 0.20 decrease). In agreement with observations made by Subuh et al. [42], our results showed a significant reduction in the immediately soluble fraction as a result of the heat treatment (table II). MichaletDoreau and Evrard [31] have also shown that raising the heating temperature and

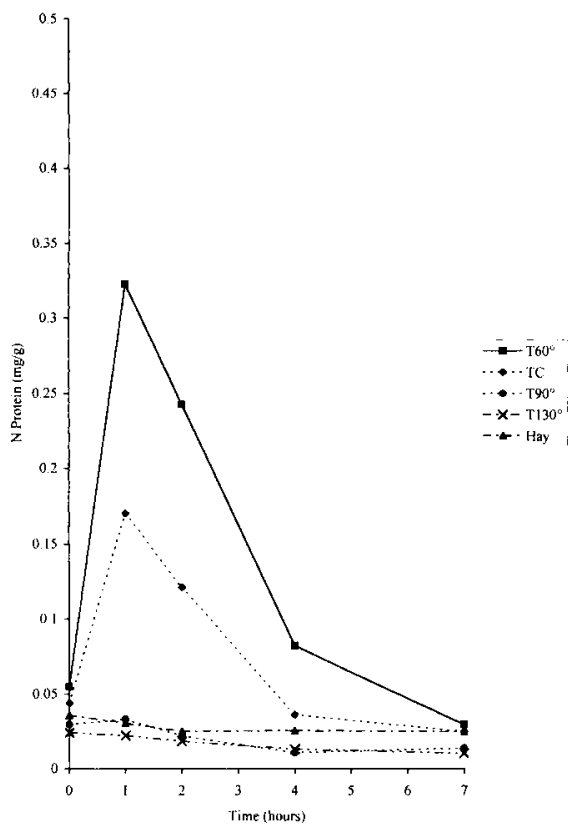

Figure 4. Evolution of protein- $\mathrm{N}$ content in rumen fluid for rations containing $\mathrm{T} 60^{\circ}, \mathrm{TC}$, $\mathrm{T} 90^{\circ}, \mathrm{T} 130^{\circ}$ and hay alone before the morning feed (TOh) and $1 \mathrm{~h}, 2 \mathrm{~h}, 4 \mathrm{~h}$ and $7 \mathrm{~h}$ after feeding.

steam injection during solvent extraction decreases degradability in the rumen considerably. This decrease can be more or less significant depending on the processing techniques $[11,22,27]$, whereas seed extrusion was shown to be inefficient in the work of Deacon et al. [12]. Technological processes, and particularly heat, may modify protein structure. The $3 D$ structure may be altered. Heating also involves Maillard reactions between carbohydrates and the free amino groups in the proteins to form covalent bonds which are resistant to enzyme hydrolysis (for reviews see $[41,46]$ ). This structural change in the feed may also inhibit the fixation of proteolytic bacteria [26].

The amount of protein extracted from the meals with the extraction solution 

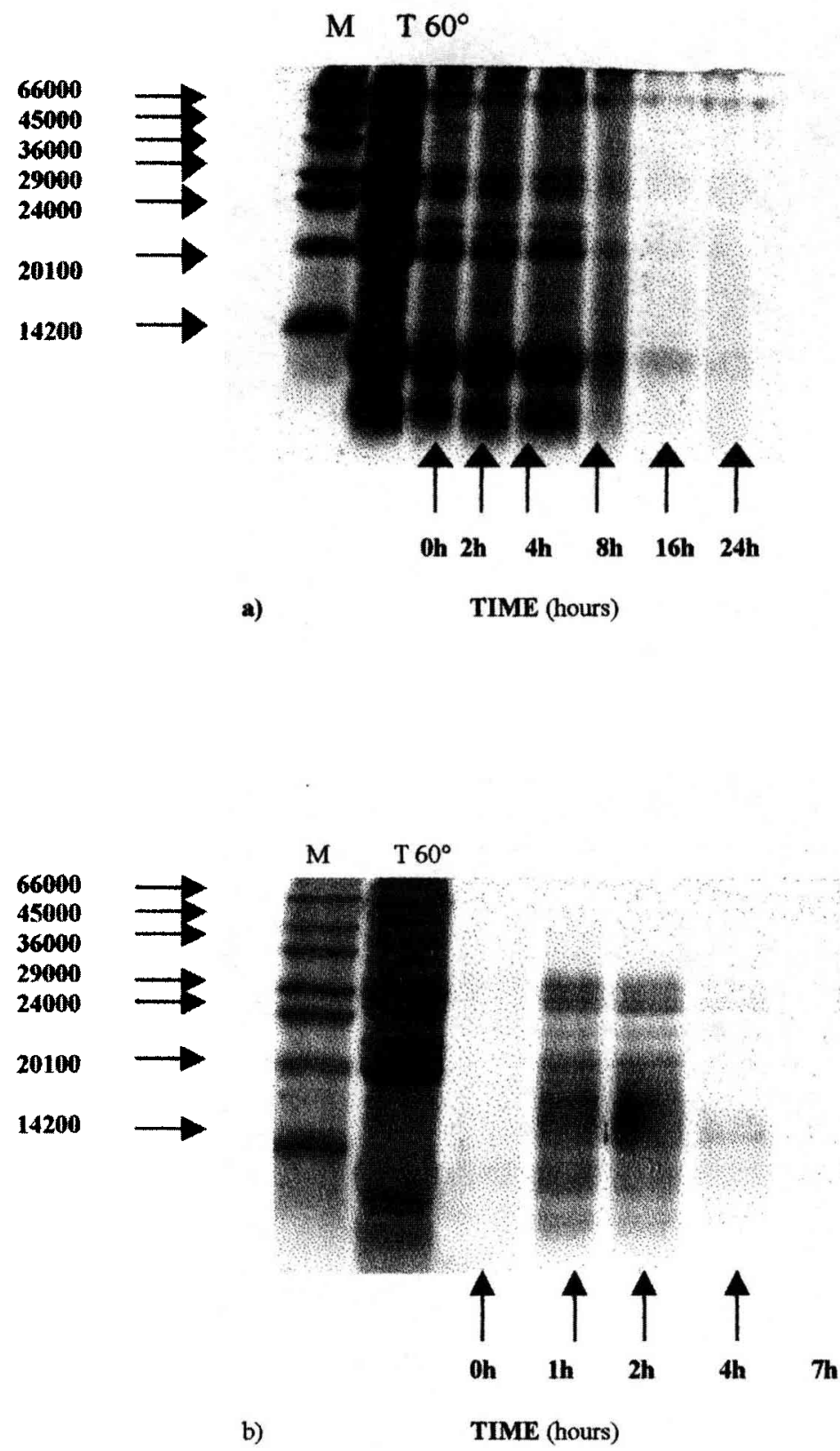

Figure 5. SDS gel electrophoresis of T60 showing residues after in situ incubation for $0 \mathrm{~h}, 2 \mathrm{~h}$, $4 \mathrm{~h}, 8 \mathrm{~h}, 16 \mathrm{~h}$ and $24 \mathrm{~h}$ in the rumen (a) and proteins in the rumen fluid for sheep receiving a ration of hay and $\mathrm{T} 60^{\circ}$, before the meal $(0 \mathrm{~h})$ and $1 \mathrm{~h}, 2 \mathrm{~h}, 4 \mathrm{~h}$ and $7 \mathrm{~h}$ after feeding $(\mathbf{b})$. M, molecular mass markers from Sigma. 
(before electrophoresis protein separation) was low for $\mathrm{T} 90^{\circ}$ and $\mathrm{T} 130^{\circ}$. Girault [16] explains these differences by the more or less significant denaturation of the proteins caused by the heat treatment during meal making. The sodium dodecyl sulfate (SDS) used in the extraction solution before protein separation by electrophoresis, also present in the neutral detergent solution (NDS) used in Van Soest's fractionation, cannot solubilize the covalent bonds that might have formed between glucose and lysine (Schiff base) during the heat treatment and solvent extraction process. Proteins linked to the NDF residue and whose nitrogen content was about $50 \% \mathrm{Nt}$ for $\mathrm{T} 90^{\circ}$ and $\mathrm{T} 130^{\circ}$ were not extracted with SDS.

In agreement with Bhatty et al. [6] and Schwenke [38], our results showed that rapeseed proteins are mostly made up of $12 \mathrm{~S}$ globulin or cruciferin, containing several molecular mass subunits (18 500, $21100,26800,31200$ molecular mass) and $1.7 \mathrm{~S}, 2 \mathrm{~S}$ albumin or napin (8000 and 10000 molecular mass). The last two are made up of two polypeptide chains linked by disulfide bonds [23]. For all the meals, whether experimental or not, the residual proteins of the samples for the four rapeseed meals incubated in the nylon bags degraded at different rates, as might be expected from the $\operatorname{Deg}(\mathrm{N})$ results. Furthermore, the various protein fractions for $\mathrm{T} 60^{\circ}$ and $\mathrm{TC}$ disappeared at the same time, while, for other rapeseed meals [2] and for $\mathrm{T} 90^{\circ}$ and $\mathrm{T} 130^{\circ}$, the 8000 molecular mass protein was rapidly degraded. As indicated previously, the amount of extracted proteins was very low for $\mathrm{T} 90^{\circ}$ and $\mathrm{T} 130^{\circ}$.

\subsection{Nitrogen forms in the ruminal fluid}

The higher Nt, NH3-N and true protein contents in ruminal fluid before the first meal compared to $7 \mathrm{~h}$ after were due to the smaller size of the rumen pool before the meal, as we found elsewhere (unpublished results). Sehgal and Makkar [39] have also showed this.

The concentration of different nitrogen fractions present in the rumen at a given time (particularly NH3-N, small size peptides) is a balance between dietary proteolysis, microbial synthesis use, absorption through the rumen wall, endogenous nitrogen flow, and transit to the small intestine.

The high crude protein content in the ration (approximately $195 \mathrm{~g} / \mathrm{kg} \mathrm{DM}$ ) explained the high $\mathrm{Nt}$ contents measured in the ruminal fluid. The high $\operatorname{Deg}(\mathrm{N})$ and the greater immediately soluble fraction (a fraction) for $\mathrm{T} 60^{\circ}$ compared with the other meals explained the high amount of total nitrogen measured in the ruminal fluid from the ration containing $\mathrm{T} 60^{\circ}$ at time $\mathrm{l} \mathrm{h}$ after feeding. The variation in $\mathrm{Nt}$ content in the ruminal fluids for diets containing $\mathrm{T} 90^{\circ}$ and $\mathrm{T} 130^{\circ}$ was much in smaller, but these meals had lower Deg(N) and were degraded more slowly.

According to Satter and Slyter [37], a minimum concentration of 5 to $8 \mathrm{mg} /$ $100 \mathrm{~mL} \mathrm{NH3-N}$ is necessary to obtain optimum microbial growth. With all the diets containing the rapeseed meals, $\mathrm{NH} 3-\mathrm{N}$ concentration in ruminal fluid was much higher than this value. Thus, it may be that bacterial activity was not altered much in the different rapeseed meals used in the ration.

For diets containing $\mathrm{T} 90^{\circ}$ and $\mathrm{T} 130^{\circ}$, ruminal fluid nitrogen was mainly as NH3-N $(60 \%$ to $70 \%$ of total $N)$. The $\mathrm{NH} 3-\mathrm{N}$ content in ruminal fluid, however, was lower than this for the diets containing $\mathrm{T} 60^{\circ}$ or TC. For the diets containing $\mathrm{T} 60^{\circ}$ and TC, the NH3-N content was higher but, in the $2 \mathrm{~h}$ following the meal, it represented a much lower proportion $\mathrm{Nt}$, as there was a transient accumulation of proteins which was confirmed by the electrophoresis results (figure 5). Spencer et 
al. [40], using rapeseed protein and pea proteins, Messman and Weiss [30], using soluble protein in fish and blood meal, and Mc Naab et al. [28], using rubisco, have also shown that these proteins could be solubilized inside the rumen without being immediately degraded as was suggested in the model from Fox et al. [14]. However, the electrophoresis results did not show any protein in the ruminal fluid at time $4 \mathrm{~h}$ after feeding. In some other in vitro studies, different values were found. For example, Spencer et al. [40] found some up to $24 \mathrm{~h}$, and Messman and Weiss [30], up to $20 \mathrm{~h}$.

The amino acids and peptide contents in the ruminal fluid, calculated by difference, were highest for all diets $1 \mathrm{~h}$ after feeding and only represented $25 \%$ of $\mathrm{Nt}$ for diets containing $\mathrm{T} 60^{\circ}, \mathrm{TC}$ and $\mathrm{T} 90^{\circ}$, but $38 \% \mathrm{Nt}$ for the ration containing $\mathrm{T} 130^{\circ}$. Rumen microbes use peptides rapidly and incorporate them efficiently into their proteins. However, if the rate of released peptides exceeds the rate of which peptides are hydrolysed or incorporated by microorganisms, peptides can accumulate and can then be detected in the ruminal fluid [9]. According to these authors, these peptides could escape degradation in the rumen and be absorbed in the intestine or partly absorbed through the rumen and the omasum $[25,49]$. The results obtained in this study for $\mathrm{T} 130^{\circ}$ disagreed with those obtained by Broderick and Wallace [7], and Broderick and Craig [8], who observed an accumulation of peptides in vitro only when feed proteins degraded rapidly (casein).

In order to estimate the consequences in terms of nutrition, it is important to quantify the extent to which NAN in ruminal fluid can contribute to the intestinal protein flow. From our results, for each of the rapeseed meals, we estimated this proportion of NAN, taking into account the nitrogen fraction from the hay (in the hay diet). The volume of rumen $(6 \mathrm{~L})$ we retained was estimated from the measurements made on the same sheep receiving a ration made up of $60 \%$ hay and $40 \%$ soya meal. The fractional passage rate for liquids was estimated at $0.07 \mathrm{~h}^{-1}$ for an ingestion rate of $1 \mathrm{~kg}$ /day according to measurements carried out by Baumont et al. [3]. Feed proteins arriving into the intestine (PIA), estimated from the $\operatorname{Deg}(\mathrm{N})$ actually measured in the nylon bags were calculated taking into account a fractional rate of outflow from the rumen of $0.06 \mathrm{~h}^{-1}$. (PIA $(\mathrm{g} / \mathrm{kg} \mathrm{DM})=1.11 \times$ CP(1-Deg(N)) with CP (g/kg DM) [48].

The ratio between the amount of NAN $\times 6.25$ in ruminal fluid able to escape degradation in the rumen and the amount of PIA, enabled us to calculate the amount of PIA that was under-estimated solely based on measuring $\operatorname{Deg}(\mathrm{N})$ in the bags. This amount is shown in table III.

Table III. Ratio between the amount of non-ammonia nitrogen (NAN) liable to escape degradation in the rumen and the PIA (dietary proteins arriving into the intestine) or degraded protein, for the various rapeseed meals.

\begin{tabular}{lcccc}
\hline & T60 & TC & T90 & T130 \\
\hline Deg $(\mathrm{N})$ & 0.826 & 0.693 & 0.391 & 0.422 \\
NAN $\times 6.25(\mathrm{~g} / \mathrm{kg})$ & 22.4 & 14.9 & 10.0 & 10.7 \\
PIA $(\mathrm{g} / \mathrm{kg})$ & 69.6 & 126.2 & 250.5 & 243.6 \\
$\mathrm{NAN} \times 6.25 / \mathrm{PIA}(\%)$ & 32.1 & 11.8 & 4.0 & 4.4 \\
$(\mathrm{CP} \times \operatorname{Deg}(\mathrm{N})(\mathrm{g} / \mathrm{kg})$ & 297.7 & 256.6 & 144.9 & 160.4 \\
$\mathrm{NAN} \times 6.25 /(\mathrm{CP} \times \mathrm{DEG}(\mathrm{N}))(\%)$ & 7.5 & 5.8 & 6.9 & 6.7 \\
\hline
\end{tabular}


It was approximately $32 \%$ for $\mathrm{T} 60^{\circ}, 12 \%$ for $\mathrm{TC}$ and $4 \%$ for $\mathrm{T} 90^{\circ}$ and $\mathrm{T} 130^{\circ}$.

Nevertheless, whatever the oilmeal, the NAN $\times 6.25$ able to escape degradation represented 5.5 to $7.5 \%$ of the amount of degraded protein $(\operatorname{Deg}(\mathrm{N}) \times \mathrm{CP})$.

\section{CONCLUSION}

For the four rapeseed meals studied, the degradability of total nitrogen assessed through the in situ method differed: 0.83 , $0.69,0.39$ and 0.42 respectively for $T 60^{\circ}$, $\mathrm{TC}, \mathrm{T} 90^{\circ}$, and $\mathrm{T} 130^{\circ}$. The main proteins were $12 \mathrm{~S}$ globulin or cruciferin and 1.7S albumin or napin. The proteins in the nylon bag residues disappeared at the same time for $\mathrm{T} 60^{\circ}$ and $\mathrm{TC}$, and more slowly for $\mathrm{T} 90^{\circ}$ and $\mathrm{T} 130^{\circ}$ except for the 8000 molecular mass protein fraction. Some soluble proteins could escape degradation in the rumen when the rapeseed meals were degraded rapidly ( $660^{\circ}$ and $\left.\mathrm{TC}\right)$. The nitrogen forms present in the ruminal fluid were proportionally different depending on the sampling times, and on the meal being studied. For the low heat meals (TC and $\left.\mathrm{T} 60^{\circ}\right), 1 \mathrm{~h}$ and $2 \mathrm{~h}$ after feeding, we observed a balance between NH3-N, protein $\mathrm{N}$, peptides and amino acids, whereas for $\mathrm{T} 90^{\circ}$ and $\mathrm{T} 130^{\circ}, 70 \%$ would be made up of NH3-N and the remaining part of amino acids and peptides, except at $1 \mathrm{~h}$ for $\mathrm{T} 130^{\circ}$, where $57 \%$ was NH3-N and $38 \%$ as amino acids and peptides. Whatever the oilmeal, the solubilized NAN represented 5.5 to $7.5 \%$ of the degraded protein. In addition, true digestibility (dr) of NAN in the small intestine, which is essentially formed of peptides and amino acids was close to 1 , even though, the dr of rapeseed meal PIA would be close to 0.80 [48].

\section{ACKNOWLEDGMENTS}

The authors would like to thank the Gie Euretec II partners (Arrive, CCPA, Cetiom,
Guyomarc'h, ITCF, Onidol, Sanders, Sofiproteol, Ucanor, Unicopa and Unip) for providing the rapeseed meals and financial help, and they would also especially like to thank MariePierre Le Guen.

\section{REFERENCES}

[1] Aufrère J., Cartailler D., Mise au point d'une méthode de laboratoire de prévision de la dégradabilité des protéines alimentaires dans le rumen, Ann. Zootech. 4 (1988) 255-270.

[2] Aufrère J., Graviou D., Utilisation de l'électrophorèse pour étudier la dégradation dans le rumen des protéines du tourteau de colza, Ann. Zootech. 43 (suppl. 1) (1994) 11s.

13] Baumont R., Jailler M., Dulphy J.P., Dynamic of voluntary intake, feeding behaviour and rumen function in sheep fed three contrasting types of hay, Ann. Zootech. 46 (1997) 231-244.

14] Bell J.M. Factors affecting the nutritional value of canola meal, a review, Can. J. Anim. Sci. 73 (1993) 679-697.

15] Bertilson J., Gonda H.L., Lindberg J.E., Effects of level and degradability of rapeseed meal in rations for dairy cows. 1. Animal performance, Acta Agric. Scand. 44 (1994) 222-229.

[6] Bhatty R.S., McKenzie S.L., Finlayson A.J., The proteins of rapessed (brassica napus L.) soluble in salt solutions, Can. J. Biochem. 46 (1968) 1191-1197.

17] Broderick G.A., Wallace R.J., Effects of dietary nitrogen source on concentrations of ammonia, free amino acids and fluorescamine-reactive peptides in the sheep rumen, J. Anim. Sci. 66 (1988) 2233-2238.

[8] Broderick G., Graig M., Metabolism of peptides and amino acids during in vitro protein degradation by mixed rumen organisms, J. Dairy Sci. 72 (1989) 2540-2548.

[91 Chen G., Sniffen C.J., Russel J.B.. Concentration and estimated flow of peptides from the rumen of dairy cattle, Effects of protein quantity, protein solubility, and feeding frequency, J. Dairy Sci. 70 (1987) 983-992.

[10] Conway E.J., Microdiffusion analysis and volumetric error, Crosby Lockwood, London, 1957.

[11] Dakowski P., Weisbjerg M.R., Hvelplund T., The effect of temperature during processing of rapeseed meal on amino acid degradation in the rumen and digestion in the intestine, Anim. Feed Sci. Technol. 58 (1996) 213-226.

112] Deacon M.A., de Boer G., Kennelly J.L., Influence of Jet-Sploding and extrusion on ruminal and intestinal disappearance of canola 
and soybeans, J. Dairy Sci. 71 (1988) 745-753.

[13] Dorléans M., Mandran N., Sauvant D., Study of the use of a protease with the van Soest procedure, Anim. Feed Sci, Technol. 61 (1996) 129-136.

[14] Fox D.G., Sniffen C.J., O'Connor J.D., Russell J.B., Van Soest P.J., A net carbohydrate and protein system for evaluating cattle diets. III. Cattle requirements and diet adequacy, J. Anim. Sci. 70 (1992) 3578-3596.

[15] Giger S., Thivend P., Sauvant D., Dorléans M., Journaix P., Étude de l'influence préalable de différentes enzymes amylolytiques sur la teneur en résidu NDF d'aliments du bétail, Ann. Zootech. 36 (1987). 39-48.

[16] Girault A., The study of some properties of rapeseed protein with a view to protein concentrate production, J. Sci. Food Agric. 24 (1973) 509-518.

[17] Grenet E., Taille et structure des particules végétales au niveau du feuillet et des fèces chez les bovins, Ann. Biol. Anim. Biochim. Biophys. 10 (1970) 643-657.

[18] Hill R., Rapeseed meal in the diet of ruminants, Nutr Abstr. Rev. (series B), 61 (1991) $139-155$.

[19] Hvelplund T., Andrieu J., Weisberg M.R., Vermorel M., Prediction of the energy and protein value of forages for ruminants, in: Journet M., Grenet E., Farce M.H., Theriez M., Demarquilly C. (Eds.), Recent developments in the nutrition of herbivores. Proceedings of the IVth International Symposium on the Nutrition of Herbivores. Clermont-Ferrand, France, 1995, pp. 205223.

[20] Inra, Recommended allowances and feed tables, in: Jarrige R. (Ed.), Ruminant Nutrition, J.L. Eurotext, London, Paris, 1989.

[21] Laemmli U.K., Cleavage of structural proteins during the assembly of the head of bacterophage T4, Nature (Lond.) 227 (1970) $680-685$.

[22] Lindberg J.E., Nitrogen metabolism in sheep. 1. Rumen fermentation and microbial protein synthesis in sheep fed rations with hay, barley and various protein supplements, Swed. J. Agric. Res. 14 (1984) 29-36

[23] Lonnerdal B., Janson J.C., Studies on Brassica seed proteins. The low molecular weight proteins in rapeseed, isolation and characterization, Biochem. Biophys. Acta 278 (1972) 175-183.

[24] Madsen J., Hvelplund T., Protein degradation in the rumen. A comparison between in vivo, nylon bag, in vitro and buffer measurements, Acta Agric. Scand., Suppl. 25 (1985) 103-124.
[25] Mathews J.C., Wong E.A., Bender P.K., Bloomquist J.R., Webb K.E., Demonstration and characterization of dipeptide transport system activity in sheep omasal epithelium by expression of mRNA in Xenopus laevis oocytes, J. Anim. Sci. 74 (1996) 1720-1727.

[26] McAllister T.A., Bae H.D., Jones G.A., Cheng K.J., Microbial attachment and feed digestion in the rumen, J. Anim. Sci. 72 (1994) 3004-3018.

[27] Mc Kinnon J.J., Olubobokun J.A., Christensen D.A., Cohen R.D.H., The influence of heat and chemical treatment on ruminal disappearance of canola meal, Can. J. Anim. Sci. 71 (1991) 773-780.

[28] Mc Naab W.C., Spencer D., Higgins T.J., Barry T.N., In vitro rates of rumen proteolysis of ribulose-1-5-biphosphate carboxylase (rubisco) from lucerne leaves, and of ovalbumin, viciline and sunfower albumin 8 storage proteins, J. Sci. Food Agric. 64 (1994) 53-61.

[29] Merry R.J., Mc Allan R.B., A comparison of the chemical composition of mixed bacteria harvested from the liquid and solid fractions of rumen digesta, Br. J. Nutr. 50 (1983) 701-709.

[30] Messman M.A., Weiss W.P., Use of electrophoresis to quantify ruminal degradability of protein from concentrate feeds, Anim. Feed Sci. Technol. 49 (1994) 25-35.

[31] Michalet-Doreau B., Evrard J., Influence du mode de trituration des tourteaux sur leur valeur azotée pour les ruminants, GCIR eight international rapeseed congress, July 9-11, Saskatoon, Saskatchewan, Canada, 1991, pp. 418-423.

[32] Michalet-Doreau B., Vérité R., Chapoutot P., Méthodologie de mesure de la dégradabilité in sacco de l'azote des aliments dans le rumen, Bull. Tech. CRZV Theix, 69 (1987) 5-7.

133] Orskov E.R., Mc Donald I., The estimation of protein degradability in the rumen from incubation measurements weighted according to rate of passage, J. Agric. Sci. Camb. 92 (1979) 499-503.

[34] Poncet C., Michalet-Doreau B., Mc Allister T., Rémond D., Dietary compounds escaping rumen digestion, in: Journet M., Grenet E., Farce M.H., Theriez M., Demarquilly C. (Eds.), Recent developments in the nutrition of herbivores, Proceedings of the IVth International Symposium on the Nutrition of Herbivores Clermont-Ferrand, France, 1995. pp. 167-194.

[35] Statistical Analysis Systems Institute Inc., SAS STAT Software, General Linear Model, SAS Institute, Cary, N.C., 1985. 
[36] Sauvant D., Prévision de la valeur énergétique des aliments concentrés et composés pour les ruminants, in: Prévision de la valeur nutritive des aliments des ruminants, Inra Publ., 1981, pp. 237-258.

[37] Satter L.D., Slyter L.L., Effect of ammonia concentration on rumen microbial protein production in vitro, Br. J. Nutr. 32 (1974) 199.

[38] Schwenke K.D., Structural studies on native and chemically modified storage proteins from rapeseed (Brassica napus L.) and related plant proteins, Die Nahrung 3 (1990) 225-240.

[39] Sehgal J.P., Makkar G.S., Protein evaluation in ruminants in vitro, in sacco, in vivo protein degradability and microbial efficiency of different protein supplements in growing buffalo calves, Anim. Feed Sci. Technol. 45 (1994) 149-165.

[40] Spencer D., Higgins T.J.V., Freer M., Dove H., Coombe J.B., Monitoring the fate of dietary proteins in rumen fluid using gel electrophoresis, Br. J. Nutr. 60 (1988) 24l-247.

[41] Stern M.D., Varga G.A., Clark J.H., Firkins J.L., Huber J.T., Palmquist D.L., Symposium, metabolic relationships in supply of nutrients for milk protein synthesis. Evaluation of chemical and physical properties of feeds that affect protein metabolism in the rumen, J. Dairy Sci. 77 (1994) 2762-2786.

[42] Subuh A.M., Rowan T.G., Lawrence T.L.J., Effect of heat of formaldehyde treatment and differences in basal diet on the rumen degradability of protein in soybean meal and in rape- seed meals of different glucosinolate content, Anim. Feed Sci. Technol. 49 (1994) 297-310.

143] Tuori M., Rapeseed meal as a supplementary protein for dairy cows on grass silage-based diet, with the emphasis on the NordicAAATPBV feed protein evaluation system, Agric Sci. Finl. 1 (1992) 367-439.

144] Van Soest P.J., Use of detergent in the anal$y$ sis of fibrous feed. I. A rapid method for the determination of fiber and lignin, J. Assoc Agric. Chem. 46 (1963) 829-835.

[45] Van Soest P.J., Wine R.H., Use of detergents in the analysis of fibrous feeds. IV. Determination of plant cell-wall constituents, J. Assoc. Off. Agric. Chem. 50 (1967) 50-55.

[46] Van Soest P.J., Nutritional ecology of the ruminant, 2nd edition, Cornell Univ. Press, 1994, 476 p.

[47] Vérité R., Valeur azotée du tourteau de colza pour les ruminants, in : Colloque Tourteau de colza 'L'enjeu', Colloque organisé par l'ONIDOL et le CETIOM, 12, avenue George-V, Paris, 1985.

[48] Vérité R., Michalet-Doreau B., Chapoutot P., Peyraud J.L., Poncet C., Révision du système des protéines digestibles dans l'intestin (PDI), Bull. Tech. CRZV Theix, Inra, 70 (1987) 19-34.

[49] Webb K.E. Jr., Dirienzo D.B., Matthews J.C. Recent developments in gastrointestinal absorption and tissue utilization of peptides, a review, in: Symposium, nitrogen metabolism and amino acid nutrition in dairy cattle, J. Dairy Sci. 76 (1992) 351-361. 